\title{
Sistem Pendukung Keputusan Penentuan Kualitas Getah Hevea brasiliensis (Karet) Terbaik pada PT Timbang Deli Verdant Bioscience dengan Metode Promethee
}

\author{
${\text { Tika Apriani*1, }{ }^{*} \text { Agustina Simangunsong }}^{2}$ \\ 1,2Teknik Informatika, STMIK Pelita Nusantara, Indonesia \\ Email: 'tikaapriani76@gmail.com, ${ }^{2}$ agustinasimangunsong93@yahoo.com
}

\begin{abstract}
Abstrak
Kualitas produk menjadi faktor terpenting dalam menjalankan suatu bisnis, kualitas produk menentukan tingkat kepuasan konsumen dan juga masa depan perusahaan. PT Timbang Deli Verdant Bioscience masih belum memanfaatkan teknologi komputer, sehingga menyebabkan waktu yang relatif lama dalam menghitung nilai kualitas getah karet, dibutuhkan teknologi komputer yang dapat mendukung pengambilan keputusan untuk memecahkan masalah yang bersifat terstruktur maupun tidak terstruktur. Diperlukan sistem yang dapat menyelesaikan masalah menentukan kualitas getah Hevea brasiliensis (karet), dengan adanya Sistem Pendukung Keputusan menentukan kualitas getah Hevea brasiliensis (karet) diharapkan dapat membantu dan mempermudah pihak perusahaan dalam memilih jenis bibit unggul kelapa sawit. Penelitian ini bertujuan menentukan kualitas getah Hevea brasiliensis karet terbaik pada PT Timbang Deli Indonesia Verdant Bioscience menggunakan metode promethee. Output aplikasi ini berbentuk keputusan alternatif dengan nilai rangking tertingi. Sistem Pendukung Keputusan dikembangkan menggunakan bahasa pemrograman PHP dan MySQL sebagai Database Management System (DBMS). Pengujian sistem menghasilkan Ranking 1 yaitu A2 dengan Leaving Flow = 0,583333 , Entering Flow $=0,583333$, Net Flow $=0$ sedangkan Ranking 2 yaitu A3 dengan Leaving Flow $=$ 0.166667 , Entering Flow $=-0,208333$, Net Flow $=0.75$ dan Ranking 3 yaitu A1 dengan Leaving Flow $=0$, Entering Flow $=0,75$, Net Flow $=-0.75$.
\end{abstract}

Kata kunci: Kualitas Getah, Metode Promethee, Ranking, SPK

\begin{abstract}
Product quality is the most important factor in running a business, product quality determines the level of customer satisfaction and also the future of the company. PT Timbang Deli Verdant Bioscience still does not utilize computer technology, thus causing a relatively long time in calculating the value of rubber latex quality, computer technology is needed that can support decision making to solve structured and unstructured problems. A system is needed that can solve the problem of determining the quality of Hevea Brasiliensis sap (rubber), with the Decision Support System to determine the quality of Hevea brasiliensis (rubber) sap, it is hoped that it can help and facilitate the company in choosing the type of superior oil palm seeds. This study aims to determine the quality of the best rubber hevea brasiliensis sap at PT Timbang Deli Indonesia Verdant Bioscience using the promethee method. The output of this application is in the form of an alternative decision with the highest ranking value. The Decision Support System was developed using the PHP programming language and MySQL as the Database Management System (DBMS). System testing resulted in Rank 1 which is A2 with Leaving Flow $=0.583333$, Entering Flow $=0.583333$, Net Flow $=0$ while Rank 2 is A3 with Leaving Flow $=0.166667$, Entering Flow $=-0.208333$, Net Flow $=0.75$ and Rank 3 is Al with Leaving Flow $=0$, Entering Flow $=0.75$, Net Flow $=-0.75$.
\end{abstract}

Keywords: Determining Sap Quality, Promethee Method, Ranking, SPK

\section{PENDAHULUAN}

Pada era globalisasi seperti sekarang ini, teknologi informasi telah menjadi pilihan utama dalam sebuah perusahaan yang tangguh dan mampu melahirkan keunggulan kompetitif di tengah persaingan yang semakin ketat. Perkembangan teknologi informasi saat ini sudah mulai merambah ke berbagai bidang kehidupan dan tidak dapat dipungkiri bahwa teknologi informasi dapat meningkatkan efektivitas dan efisiensi kerja suatu perusahaan. Peranan teknologi informasi dalam berbagai bidang 
kehidupan dapat dipahami karena sebagai sebuah teknologi yang menitikberatkan pada pengaturan sistem informasi dengan penggunaan komputer. PT Timbang Deli Verdant Bioscience merupakan salah satu perusahaan perkebunan swasta yang menghasilkan getah karet terbesar di Indonesia. Sistem pendukung keputusan merupakan sistem informasi interaktif yang menyediakan informasi, pemodelan, dan pemanipulasian data. Tujuannya adalah untuk membantu pengambil keputusan memilih berbagai alternatif keputusan yang merupakan hasil pengolahan informasi-informasi yang diperoleh atau tersedia dengan menggunakan model pengambilan keputusan [1].

Beberapa metode yang dapat digunakan untuk membangun SPK, salah satunya adalah metode Promethee. Promethee (Preference Ranking Organization Method for Enrichment Evaluation) merupakan suatu metode yang menggunakan tipe preferensi dalam perhitungannya. Promethee menyediakan kepada user untuk menggunakan data secara langsung dalam bentuk tabel multikriteria sederhana. Promethee mempunyai kemampuan untuk menangani banyak perbandingan, pengambil keputusan hanya mendefinisikan skala ukurannya sendiri tanpa batasan, untuk mengindikasi prioritasnya dan preferensi untuk setiap kriteria dengan memusatkan pada nilai (value), tapa memikirkan tentang metode perhitungannya [2].

Pemecahan permasalahan menerapkan metode pengambilan keputusan berbasis komputer yang mengolah data getah Hevea brasiliensis (karet) pada PT Timbang Deli Verdant Bioscience untuk mendapatkan keputusan sesuai dengan yang diharapkan. Metode yang digunakan adalah Promethee, karena sistem kerja perangkingan yang dimiliki Promethee sangat cocok dalam mengekspresikan kritera-kriteria yang diperlukan [3]. Promethee menyediakan kepada user untuk menggunakan data secara langsung dalam bentuk tabel multikriteria sederhana. Promethee mempunyai kemapuan untuk menangani banyak perbandingan, pengambil keputusan hanya mendefinisikan skala ukurannya sendiri tanpa batasan, untuk mengindikasi prioritasnya dan preferensi untuk setiap kriteria dengan memusatkan pada nilai (value), tanpa memikirkan tentang metode perhitungannya [4].

Pada saat ini penentuan kualitas Hevea brasiliensis (karet) terbaik Pada PT Timbang Deli Verdant Bioscience tidak memiliki sistem yang dapat menentukan kualitas getah terbaik, sehingga menyebabkan tidak akuratnya dalam menentukan kualitas getah terbaik, karena tidak adanya sistem pendukung yang mampu menentukan kualitas getah karet terbaik tersebut [5]. Maka dari itu dibutuhkan sebuah sistem untuk membantu menentukan kualitas getah Hevea brasiliensis (karet) terbaik Pada PT Timbang Deli Verdant Bioscience. Penelitian Sistem Pendukung Keputusan Penentuan Daerah Tanaman Kelapa Sawit dengan Metode Promethee. Dengan menggunakan teknik pengambilan keputusan Promethee dapat membantu para petani atau pengusaha pengambilan keputusan berdasarkan hasil parameter yaitu rangking dan persentase setiap kabupaten atau alternatif [6].

Dengan adanya sistem pendukung keputusan pemilihan bibit kelapa sawit dengan menerapkan metode Promethee II yang diharapkan dapat membantu dan mempermudah masyarakat dalam memilih jenis bibit unggul kelapa sawit, serta menambah wawasan masyarakat tentang jenis bibit unggul kelapa sawit [7]. Sistem ini, memiliki kemampuan untuk menambah alternatif komoditi sayuran, memilih tipe preferensi dari 6 tipe yang disediakan, dan mengolah data sehingga diperoleh hasil akhir berupa rangking alternatif komoditi sayuran yang disarankan untuk ditanam [8]. Metode Promethee termasuk ke dalam kelompok pemecahan masalah Multi Criteria Decision Making (MCDM) atau pengambilan keputusan kriteria majemuk yang merupakan disiplin ilmu yang sangat penting dalam pengambilan keputusan atas suatu masalah yang memiliki lebih dari satu kriteria (multikriteria) [9].

Metode Preference Ranking Organization Method For Enrichment Evaluation (Promethee) adalah suatu metode penentuan urutan (prioritas) dalam analisis multikriteria. Dugaan dari dominasi kriteria yang digunakan dalam Promothee adalah penggunaan nilai dalam hubungan outranking [10]. Metode outranking adalah metode yang dapat menangani kriteria kualitatif (kriteria yang berupa katakata) dan kriteria kuantitatif (kriteria yang dinyatakan dalam bentuk angka, hasil perhitungan dan pengukuran) secara bersamaan. Semua parameter yang dinyatakan mempunyai pengaruh nyata menurut pandangan ekonomi. menyelesaikan masalah menentukan kualitas getah Hevea brasiliensis (karet), dengan adanya Sistem Pendukung Keputusan menentukan kualitas getah Hevea brasiliensis (karet) diharapkan dapat membantu dan mempermudah pihak perusahaan dalam memilih jenis bibit 
unggul kelapa sawit. Penelitian ini bertujuan menentukan kualitas getah Hevea brasiliensis karet terbaik pada PT Timbang Deli Indonesia Verdant Bioscience menggunakan metode Promethee.

Metode Promethee (Preference Ranking Organization Method for Enrichment Evaluation) adalah satu dari beberapa metode penentuan urutan atau prioritas dalam analisis multikriteria. Metode ini dikenal sebagai metode yang efisien dan simple, tetapi juga yang mudah diterapkan dibanding dengan metode lain untuk menuntaskan masalah multikriteria. Data kriteria penelitian terdiri dari warna karet, tingkat elastis karet, waktu penyadapan dan kadar air karet. Penerapan metode Promethee untuk tahapan yang dilakukan untuk menentukan kualitas getah Hevea brasiliensis (karet) terbaik dengan metode Promethee, selanjutnya menentukan alternatif dan kriteria-kriteria yang ada. Proses ini sama halnya dengan proses normalisasi menghasilkan nilai terbesar yang akan terpilih sebagai alternatif yang terbaik.

\section{METODE PENELITIAN}

Metode penelitian merupakan tahapan-tahapan yang akan dilakukan dalam rangka penyelesaian permasalahan, Gambar 1.

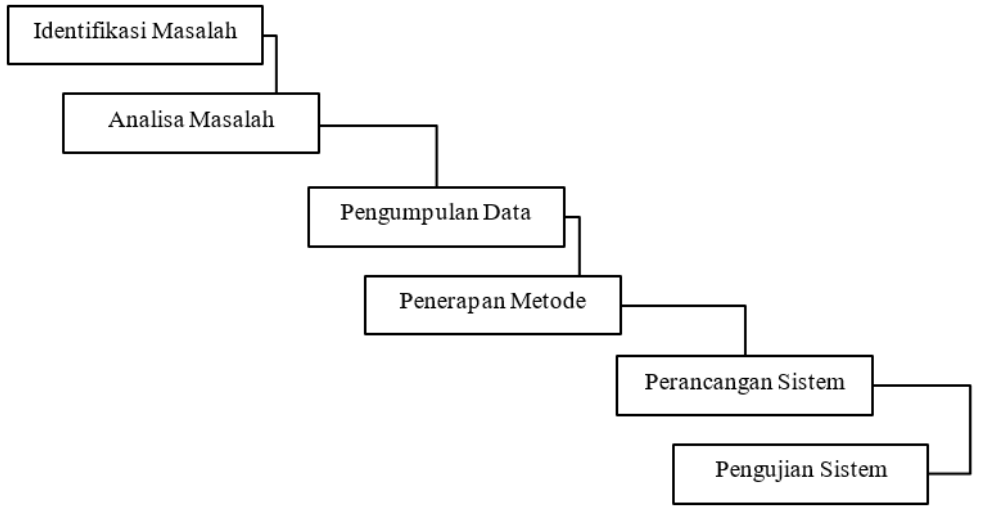

Gambar 1. Metode Penelitian

Metode penelitian menguraikan metodologi penelitian dan kerangka kerja yang digunakan dalam menyelesaikan masalah penelitian pelaksanaannya secara bertahap :

1. Identifikasi Masalah

Pada tahap ini untuk menentukan inti dari masalah-masalah yang berkaitan judul penelitian dengan metode Promethee sehingga dapat mengetahui masalah-masalah yang ada pada penelitian tersebut. Proses dan hasil pengenalan masalah atau inventarisasi masalah.

2. Analisis Masalah

Proses identifikasi masalah akan menimbulkan sebuah permasalahan yang kemudian akan dianalisis. Proses dalam analisis masalah penelitian adalah langkah untuk memahami masalah yang telah ditemukan dan ditentukan. Dengan menganalisis permasalahan yang telah ditemukan dan ditentukan tersebut, maka masalah tersebut dapat dipahami dan dianalisis dengan baik.

3. Pengumpulan Data

Pengumpulan data merupakan salah satu tahap untuk menentukan penyelesaian suatu masalah secara ilmiah. Data yang didapatkan dari hasil wawancara dan observasi terhadap pihak PT Timbang Deli Verdant Bioscience. Data yang digunakan berupa jenis-jenis penentuan kualitas getah dari sumber sebagai karet dan apa saja kriteria/atribut yang menentukan kualitas getah keret pada narasumber PT Timbang Deli Verdant Bioscience, mengambil beberapa sampel data alternatif getah karet yang akan digunakan sebagai bahan pengujian menggunakan metode Promethee. Observasi merupakan pengamatan langsung pada objek yang diteliti. Metode ini bertujuan untuk dapat mengetahui langsung bagaimana alur kerja yang terjadi pada objek yang diteliti. Setelah melakukan pengamatan, dilakukan pencatatan secara sistematis dari hasil pengamatan tersebut. Studi pustaka merupakan tahap melakukan pembelajaran mengenai penerapan sistem pendukung keputusan metode Promethee sebagai metode yang digunakan untuk 
menentukan kualitas getah Hevea brasiliensis (karet) terbaik dan mempelajari teori tentang penentuan kualitas getah Hevea brasiliensis (karet) Teknik pembelajaran ini berasal dari jurnaljurnal dan buku-buku yang terkait konsep sistem pendukung keputusan, tentang metode promethe dan teori tentang getah karet.

4. Analisa Data Kualitas Getah

Pada tahap ini, data yang telah ditentukan akan dianalisis guna melengkapi dan memenuhi kebutuhan sistem yaitu dengan cara: menentukan data kriteria, alternatif, akan digunakan dalam menentukan kualitas getah terbaik, sesuai dengan hasil studi literatur, wawancara, dan observasi yang dilakukan.

5. Pengolahan Data

Pengolahan metode Promethee yang menentukan kualitas getah keret terbaik pada PT Timbang Deli Verdant Bioscience ini adalah keputusan analisis multi-kriteria. Metode ini dikenal sebagai metode yang efisien dan simple, tetapi juga yang mudah diterapkan dibanding metode lain untuk menuntaskan masalah multikriteria. Metode ini mampu mengakomodir kriteria pemilihan yang bersifat kuantitatif dan kualitatif. Dominasi kriteria yang digunakan dalam Promethee adalah penggunaan nilai dalam hubungan outranking

6. Perancangan Sistem

Desain sistem yang akan dibangun dengan cara menggunakan beberapa alat dalam merancang sebuah sistem seperti use case diagram, entity relationship diagram untuk basis data, diagram activity dan lain sebagainya untuk keperluan perancangan perangkat lunak sistem pendukung keputusan.

7. Pengujian Sistem

Pengujian pada aplikasi yang telah dibangun. sistem akan diuji menggunakan data input yang telah diperoleh dari PT Timbang Deli Verdant Bioscience yaitu berupa beberapa kriteria dari getah karet. Data tersebut dihitung menggunakan sistem yang telah dibangun sehingga menghasilkan alternatif dari getah karet mana saja yang memiliki kualitas terbaik.

\section{HASIL DAN PEMBAHASAN}

Proses Perhitungan pada Promethee Nilai f merupakan nilai nyata suatu kriteria: $\mathrm{f}: \mathrm{K} \rightarrow \mathfrak{R}$ Setiap alternatif $a \in K, f(a)$ merupakan evaluasi dari alternatif tersebut untuk suatu kriteria. Pada saat dua alternatif dibandingkan, $\mathrm{a}, \mathrm{b} \in \mathrm{K}$, harus dapat ditentukan perbandingan preferensinya. Penyampaian intensitas $(\mathrm{P})$ dari preferensi alternatif a terhadap alternatif $\mathrm{b}$ sedemikian rupa sehingga:

a. $\quad P(a, b)=0$, berarti tidak ada beda (indifference) antara a dan $b$, atau tidak ada preferensi dari a lebih baik dari $b$.

b. $\quad \mathrm{P}(\mathrm{a}, \mathrm{b}) \sim 0$, berarti lemah preferensi dari a lebih baik dari $\mathrm{b}$.

c. $\quad \mathrm{P}(\mathrm{a}, \mathrm{b}) \sim 1$, berarti kuat preferensi dari a lebih baik dari $\mathrm{b}$.

d. $\quad P(a, b)=1$, berarti mutlak preferensi dari a lebih baik dari $b$.

Dalam metode ini, fungsi preferensi seringkali menghasilkan nilai fungsi berbeda antara dua evaluasi, sehingga:

$\mathrm{P}(\mathrm{a}, \mathrm{b})$ : preferensi perbandingan alternatif a dan $\mathrm{b}$.

$f(a) \quad$ : nilai alternatif pada kriteria a.

f (b) : nilai alternatif pada kriteria b.

Data alternatif dan kriteria yaitu data penentuan kualitas getah terbaik yang didapat dari PT Timbang Deli Verdant Bioscience, dimana data yang digunakan nantinya berupa data yang terdapat informasi seperti kriteria warna karet, tingkat elastis karet, waktu penyimpanan, dan kadar air karet.

Tabel 1. Alternatif Kriteria

\begin{tabular}{lll}
\hline Kode Kriteria & Nama Kritera & Bobot \\
\hline K1 & Warna karet & 2 \\
K2 & Tingkat elastis karet & 3 \\
K3 & Waktu penyadapan & 3 \\
K4 & Kadar air karet & 3 \\
\hline
\end{tabular}


Tabel 2. Data Sub Kriteria Berdasarkan Prioritas

\begin{tabular}{llll}
\hline Kriteria & Sub Kriteria & Bobot Penilaian & Tingkat Prioritas \\
\hline \multirow{3}{*}{ Warna karet } & Hitam & 1 & Buruk \\
& Putih & 2 & Sedang \\
& Kuning & 3 & Baik \\
\multirow{5}{*}{ Tingkat elastis karet } & $25 \%$ & 1 & Buruk \\
& $50 \%$ & 2 & Sedang \\
\multirow{5}{*}{ Waktu penyadapan } & $75 \%$ & 3 & Baik \\
& Pukul > 8 pagi & 1 & Buruk \\
\multirow{3}{*}{ Kadar air karet } & Pukul 7 pagi & 2 & Sedang \\
& Pukul 5-6 pagi & 3 & Baik \\
& $<20 \%$ & 1 & Buruk \\
& $<25 \%$ & 2 & Sedang \\
\hline
\end{tabular}

Metode Promethee (Preference Ranking Organization Method for Enrichment Evaluation) adalah satu dari beberapa metode penentuan urutan atau prioritas dalam analisis multikriteria. Metode ini dikenal sebagai metode yang efisien dan simple, tetapi juga yang mudah diterapkan dibanding dengan metode lain untuk menuntaskan masalah multikriteria. Penerapan metode Promethee untuk tahapan yang dilakukan untuk menentukan kualitas getah Hevea brasiliensis (karet) terbaik dengan metode Promethee, selanjutnya menentukan alternatif dan kriteria-kriteria yang ada. Proses ini sama halnya dengan proses normalisasi. Proses ini hanya menghasilkan nilai terbesar yang akan terpilih sebagai alternatif yang terbaik.

Data penilaian didapat dari masing-masing kriteria, lalu dibuat suatu tingkat kepentingan kriteria berdasarkan nilai bobot yang ditentukan ke dalam bilangan fuzzy. Rating kecocokan setiap alternatif pada setiap kriteria, Buruk $=1$ Sedang $=2$ Baik $=3$.

Berdasarkan kriteria dan rating kecocokan setiap alternatif yang telah ditentukan, selanjutnya diberikan nilai / bobot setiap alternatif pada setiap kriteria yang telah ditentukan. Untuk setiap kriteria memiliki bobot yang dapat digunakan sebagai parameter menentukan kualitas getah Hevea brasiliensis (karet) terbaik, bobot penilaian kriteria:

Tabel 3. Sub Kriteria Berdasarkan Prioritas

\begin{tabular}{lcc}
\hline Kriteria & Sub Kriteria & Bobot Penilaian \\
\hline \multirow{3}{*}{ Warna karet } & Hitam & 1 \\
& Putih & 2 \\
Tingkat elastis karet & Kuning & 3 \\
& $25 \%$ & 1 \\
& $50 \%$ & 2 \\
Waktu penyadapan & $75 \%$ & 3 \\
& Pukul > 8 pagi & 1 \\
Kadar air karet & Pukul 7 pagi & 2 \\
& Pukul 5 - 6 pagi & 3 \\
& $<20 \%$ & 1 \\
& $<25 \%$ & 2 \\
\hline
\end{tabular}

Dari tabel kriteria di atas dibuatkan data untuk evaluasi dengan metode Promethee. Dalam sistem pendukung keputusan ini, nilai yang diterima oleh pengguna dalam menentukan kualitas getah Hevea brasiliensis (karet) terbaik berdasarkan kriteria yang ada. 
Tabel 4. Nilai Index Preferensi

\begin{tabular}{|c|c|c|c|}
\hline & A1 & A2 & A3 \\
\hline A1 & - & 0 & 0 \\
\hline A2 & 1 & - & 0,75 \\
\hline A3 & 0,5 & 0 & - \\
\hline
\end{tabular}

a. Menghitung Leaving Flow

Leaving flow adalah jumlah nilai garis lengkung yang memiliki arah menjauh dari simpul a dan ini merupakan karakter pengukuran outranking.

$$
\phi+(a)=\frac{1}{n-1} \sum_{x \in A} \varphi(a, x)
$$

$$
\begin{aligned}
& \mathrm{A} 1=1 /(4-1)(0+0) \\
& =0,00 \\
& \mathrm{~A} 2=1 /(4-1)(1+0,75) \\
& =0,583333 \\
& \mathrm{~A} 3=1 /(4-1)(0,75+0) \\
& =0.166667
\end{aligned}
$$

b. Menghitung Entering Flow

$$
\begin{array}{ll} 
& \phi-(a)=\frac{1}{n-1} \sum_{x \in A} \varphi(a, x) \\
\text { A1 }=1 /(4-1)(1+0,5) & =0,75 \\
\text { A2 }=1 /(4-1)(0+0) & =0,00 \\
\text { A3 }=1 /(4-1)(0+0,75) & =0,375
\end{array}
$$$$
\mathrm{A} 2=1 /(4-1)(0+0) \quad=0,00
$$
flow :

Berdasarkan pada nilai masing-masing leaving flow dan entering flow sehingga diperoleh net

Tabel 5. Promethee

\begin{tabular}{lll}
\hline Alternaif & Leaving Flow & Entering Flow \\
\hline A1 & 0,00 & 0,75 \\
A2 & 0,583333 & 0,00 \\
A3 & 0.166667 & 0,375 \\
\hline
\end{tabular}

c. Menghitung Net Flow

Berdasarkan pada nilai masing-masing leaving flow dan entering flow dengan persamaan rumus, sehingga diperoleh net flow:

$$
\phi(a)=\phi+(a)-\phi^{-}(a)
$$

$$
\begin{array}{ll}
\text { A1 }=0,00-0,75 & =-0,75 \\
\text { A2 }=0,583333-0,00 & =0,583333 \\
\text { A3 }=0.166667-0,375 & =-0,208333
\end{array}
$$

d. Hasil Penilaian Perangkingan

Berdasarkan perhitungan net flow diatas maka dapat diperoleh ranking masing-masing dari setiap alternatif. Jika alternatif menghasilkan nilai minus berarti lebih besar nilai entering flow daripada nilai leaving flow.

Tabel 6. Rangking Metode Promethee

\begin{tabular}{lllll}
\hline Alternatif & Leaving Flow & Entering Flow & Net Flow & Rangking \\
\hline A2 & 0,583333 & 0 & 0,583333 & 1 \\
A3 & 0.166667 & 0,375 & $-0,208333$ & 2 \\
A1 & 0 & 0,75 & $-0,75$ & 3 \\
\hline
\end{tabular}


Berdasarkan hasil perhitungan menggunakan metode Promethee untuk menentukan kualitas getah Hevea brasiliensis (karet) terbaik maka nilai terbesar adalah alternatif A2. Tahap implementasi sistem yaitu proses pembuatan sistem atau perangkat lunak dari tahap perancangan atau desain sistem tahap coding dengan menggunakan bahasa pemrograman PHP dan database mysql yang akan menghasilkan system atau perangkat lunak yang telah dirancang. Impelementasi Sistem Pendukung Keputusan Menentukan Kualitas Getah Hevea Brasiliensis (Karet) Terbaik Dengan Metode Promethee sebagai berikut:

1. Tampilan Halaman Kriteria

Halaman kriteria merupakan halaman yang digunakan admin untuk menginput, mengubah dan menghapus data kriteria, Gambar 2.

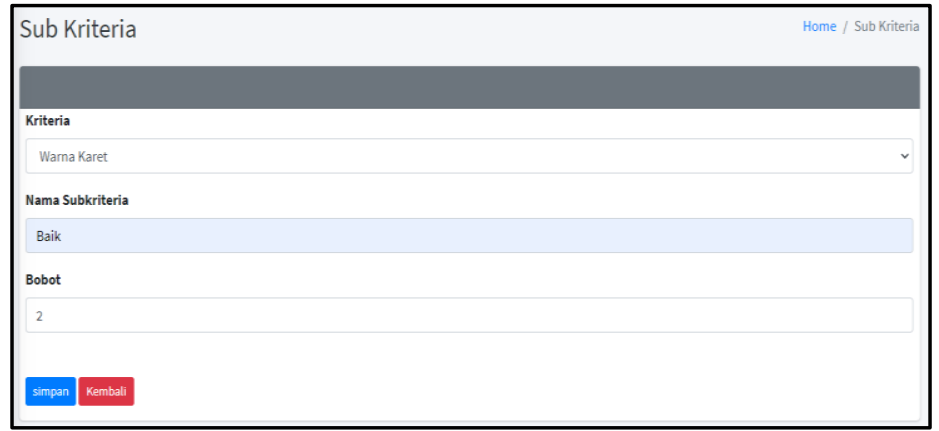

Gambar 2. Tampilan Halaman Kriteria

\section{Tampilan Halaman Alternatif}

Halaman alternatif merupakan halaman yang digunakan admin untuk menginput, mengubah, dan menghapus data alternatif, Gambar 3.

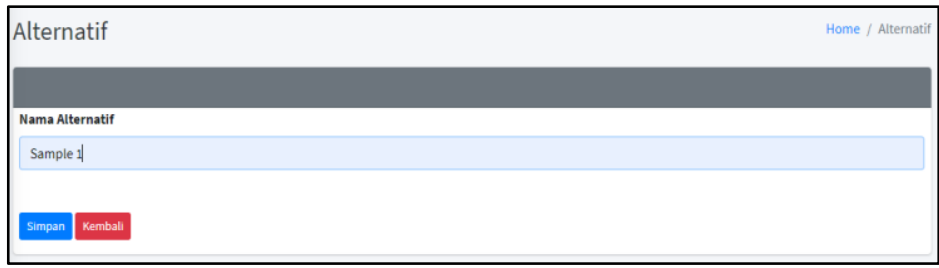

Gambar 3. Halaman Alternatif

\section{Tampilan Halaman Preferensi}

Halaman preferensi merupakan halaman yang digunakan admin untuk menginput, mengubah, dan menghapus data preferensi, Gambar 4.

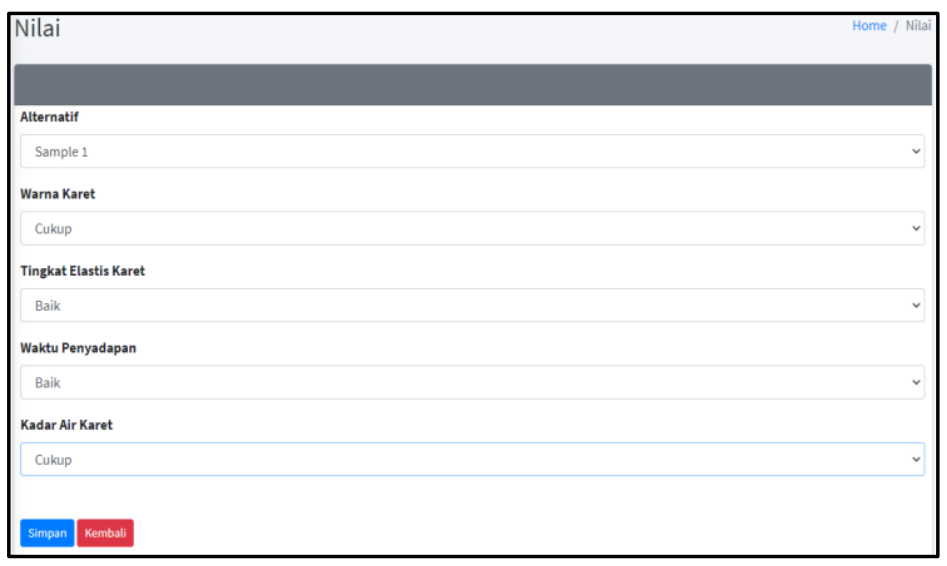

Gambar 4. Halaman Preferensi 


\section{Tampilan Halaman Pengujian Sistem}

Halaman yang digunakan admin untuk melihat hasil perhitungan metode promethea dari hasil inputan nilai pada setiap kriteria dan alternatif, Gambar 5.

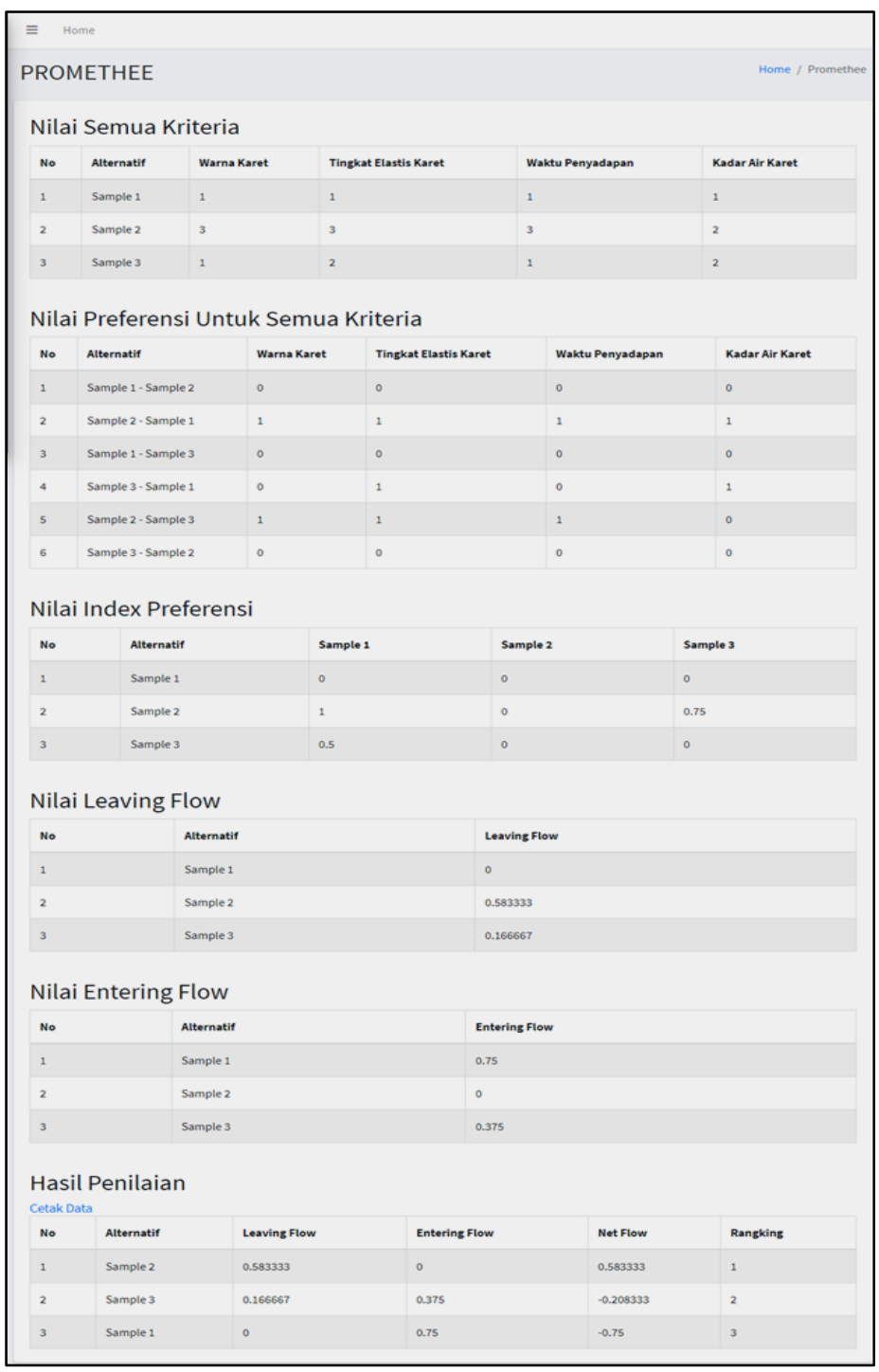

Gambar 5. Halaman Pengujian Sistem

\section{Tampilan Halaman Promethee}

Halaman prometee merupakan halaman yang digunakan admin untuk melihat hasil perhitungan metode promethea dari hasil inputan nilai pada setiap kriteria dan alternatif. Halaman hasil perhitunhan promethea merupan hasil perhitungan nilai setiap alternatif berdasarkan kriteria, subkriteria, preferensi beserta informasi perhitungan metode promethee, Gambar 6.

\begin{tabular}{|c|c|c|c|c|c|}
\hline \multicolumn{6}{|c|}{$\begin{array}{l}\text { Sistem Pendukung Keputusan } \\
\text { Menentukan Kualitas Getah Hevea Brasiliensis (Karet) Terbaik Dengan Metode Promethee }\end{array}$} \\
\hline No & Atemaif & Leasing Flow & Entrening Flow & Netflow & Rangking \\
\hline 1 & Sample2 & 0.5830333 & 0 & 0.583333 & 1 \\
\hline 2 & Sanple 3 & 0.1665667 & 0.375 & -4208333 & 2 \\
\hline 3 & Sample 1 & 0 & 0.75 & -4.75 & 3 \\
\hline
\end{tabular}

Gambar 6. Halaman Promethee 


\section{KESIMPULAN}

Kesimpulan dari penelitian menghasilkan perhitungan metode Promethee diperoleh menggunakan aplikasi sehingga memudahkan user melakukan perhitungan dengan komputerisasi. Data kriteria, subkriteria dibuat secara dinamis sehingga penggunaan sistem dapat dikembangkan sesuai kualitas getah yang ditetapkan. Berdasarkan hasil perhitungan menggunakan metode Promethee untuk menentukan kualitas getah Hevea brasiliensis (karet) terbaik maka nilai terbesar adalah alternatif A2 Ranking 1 yaitu A2 dengan Leaving Flow $=0,583333$, Entering Flow $=0,583333$, Net Flow $=0$.

\section{DAFTAR PUSTAKA}

[1] Andani, "Sistem Pendukung Keputusan Menentukan Kenaikan Jabatan Pegawai Kantor Kejaksaan Negeri Pematangsiantar Menggunakan Metode," Kaji. Ilm. Inform. dan Komput., vol. 1, no. 5, pp. 199-203, 2021.

[2] R. Anjasmaya and S. Andayani, "Sistem Pendukung Keputusan Penentuan Komoditi Sayuran Berdasarkan Karakteristik Lahan Menggunakan Metode PROMETHEE," JUITA J. Inform., vol. 6, no. 2, p. 127, 2018, doi: 10.30595/juita.v6i2.3505.

[3] T. Imandasari and A. P. Windarto, "Sistem Pendukung Keputusan dalam Merekomendasikan Unit Terbaik di PDAM Tirta Lihou Menggunakan Metode Promethee," J. Teknol. dan Sist. Komput., vol. 5, no. 4, p. 159, 2017, doi: 10.14710/jtsiskom.5.4.2017.159-165.

[4] K. Informasi and P. Data, "Jurnal widya bhumi," vol. 1, no. 5, pp. 58-64, 2021.

[5] D. M. Informatika, F. Teknik, U. N. Surabaya, T. Informatika, F. Teknik, and U. N. Surabaya, "PARFUME MENGGUNAKAN METODE PROMETHEE Dwi Ana Oktavianti Asmunin," no. 14, pp. 1-11, 1994.

[6] A. S. Nasution, "Sistem Pendukung Keputusan Pemilihan Nasabah Prioroitas Untuk Asuransi Davestera Menggunakan Metode PROMETHEE II," J. Comput. Syst. Informatics, vol. 2, no. 2, pp. 169-175, 2021.

[7] S. R. Ningsih and A. P. Windarto, "Penerapan Metode Promethee II pada Dosen Penerima Hibah P2M Internal," InfoTekJar (Jurnal Nas. Inform. dan Teknol. Jaringan), vol. 3, no. 1, pp. 20-25, 2018, doi: 10.30743/infotekjar.v3i1.641.

[8] S. L. Priestnall et al., "SISTEM PENDUKUNG KEPUTUSAN MENGGUNAKAN METODE PROMETHEE UNTUK SELEKSI PENERIMAAN MAHASISWA BARU," Endocrine, vol. 9, no. May, p. 6, 2020, [Online]. Available: https://www.slideshare.net/maryamkazemi3/stability-ofcolloids\%0Ahttps://barnard.edu/sites/default/files/inline/student_user_guide_for_spss.pdf\%0A http://www.ibm.com/support\%0Ahttp://www.spss.com/sites/dmbook/legacy/ProgDataMgmt_SPSS17.pdf\%0Ahttps://www.n.

[9] N. Sagala, J. Junita, and C. Hayat, "Sistem Pendukung Keputusan Pembelian Sepeda Motor Menggunakan Metode Promethee," Komputika J. Sist. Komput., vol. 9, no. 2, pp. 123-129, 2020, doi: 10.34010/komputika.v9i2.2916.

[10] R. Thabrani, "Sistem Pendukung Keputusan Penentuan Harga Kartu Paket Internet Dengan Metode Promethee," vol. VIII, no. 1, pp. 204-213. 


\section{Halaman Ini Dikosongkan}

